\title{
Bilateral Tessier Number 4 and 5 Facial Cleft: Case report \& Review of literature
}

\author{
Dr. Tofiq Bohra* and Dr. Parit Ladani \\ Brahma Kumari's BSES Global hospital, India
}

Submission: December 19, 2017; Published: January 08, 2018

*Corresponding author: Dr Tofiq Bohra (BDS, PGDEMS, MDS [OMFS], FCLPS), Brahma Kumari's BSES Global hospital, India, Email: drtofiqbohra@gmail.com

\begin{abstract}
Oblique clefts of the face are rare anomalies. They accounts for $0.22 \%$ of all facial clefts. A rare case of facial cleft that fits into anatomic description of Tessier no. $5 \& 4$ is reported here. Review of literature regarding the surgical management of such rare clefts has been discussed in this article along with the technique used in this case.

Keywords: Rare facial clefts; Tessier 5 \& 4; Lateral maxillary dysplasia; Oro ocular cleft; Multiple Z plasty
\end{abstract}

\section{Introduction}

Craniofacial clefts are rare congenital anomalies with incidence ranging from 1.43 to 4.85 per 100,000 live births [1]. Oblique facial clefts constitute approximately $0.22 \%$ of all facial clefts [2]. Most of the clefts that we see affect the lips, palate, alveolus, nose, but facial clefts involve the facial regions such as cheeks, eyes, nose, forehead and affect the bones as well in the same region. Tessier 4 \& 5 facial clefts are a very rare congenital deformity which involves a multi disciplinary approach towards addressing the cleft deformity. The tessier 5 cleft begins just medial to the upper lip commisure and extends across the cheek as a groove ending at the junction of the middle and lateral thirds of the lower eyelid. The inferior eyelid has a coloboma in the middle third and the orbital floor is cleft, with shortening of the distance between the oral commissure and the lower eyelid [3]. There is an alveolar cleft in the premolar region that extends across the maxilla lateral to the infraorbital nerve, up to the infraorbital rim and orbital floor. Number 4 Tessier facial cleft begins between cupid bow and oral commissure; skirting the nose and pass through cheek and lateral to lacrimal duct. Bony involvement consists of alveolar ridge, maxillary bone medial to infra orbital foramen and orbital rim and floor [4].

Morian first drew attention to the infraorbital foramen in distinguishing tessier 5 cleft from tessier 4 cleft. In tessier 5 cleft the cleft passes lateral to the infraorbital foramen, whereas in tessier 4 cleft the cleft passes medial to the infraorbital foramen. The goals of the surgical procedure include closure of the labiomaxillary cleft, reconstructing the lower eyelid, repositioning the lateral canthus, and restoration of the skeletal continuity (including the orbital floor defect) with bone grafts [3].

Case Report
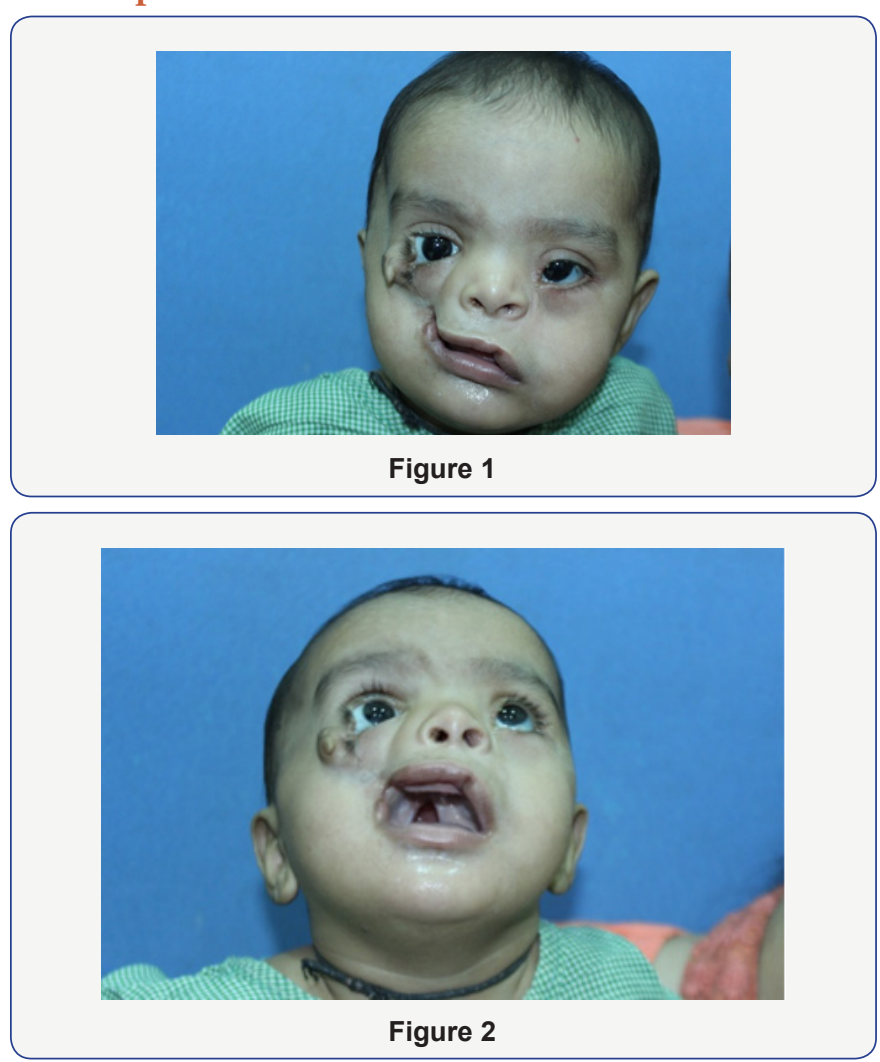
A 7 months old baby $8.3 \mathrm{~kg}$ weight reported to our department of cleft and craniofacial plastic surgery with right side tessier 5 and left side tessier 4 cleft deformity. All examinations were done to rule out any known syndrome (Figure $1 \& 2$ ).

The cleft extended 5 to $6 \mathrm{~mm}$ medially from the commissure extending to the right maxilla anteriorly from the lateral to the alveolar process of the right upper canine extending posteriorly along the hard palate medial to the alveolar ridges of the molars. The cleft is seen extending cranially to the posterior part of the inferior wall of the orbit posterior to the developing maxillary sinus. The given extend was confirmed by a Ct-Scan report confirming the cleft as teissier type 5 facial cleft (Figure 3).

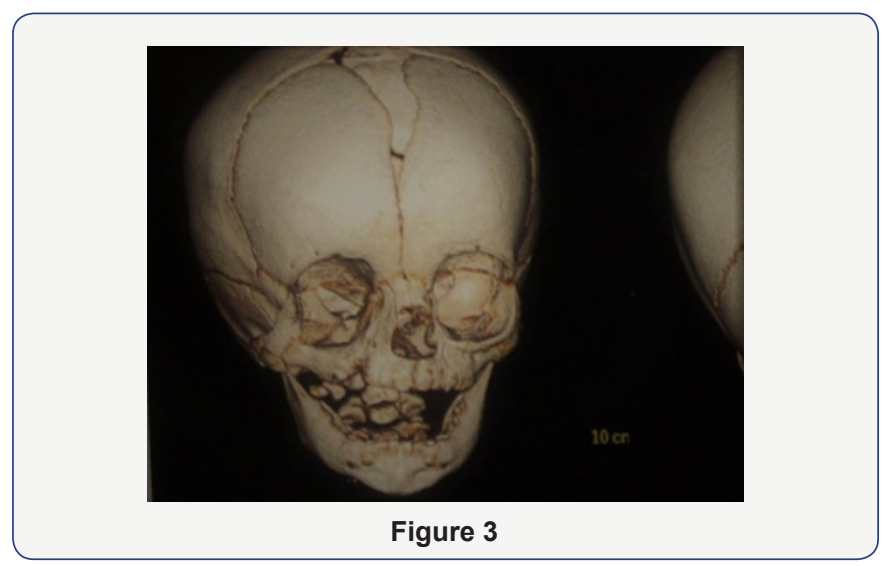

Patient was taken under GA, three triangular Z plasties were planned one to approximate the white roll, one on the cheek region to break a straight line closure to avoid contracture, last triangular Z plasty was done in the lower eyelid region, tissue tag was debulked and included in the closure as a straight line. Orbicularis oris muscle was approximated and skin closure achieved. Palatoplasty for the patient was done at a later stage at the age of 1 year which was uneventuful. Patient follow of a year reveals good healing with minimum contracture (Figure 4).

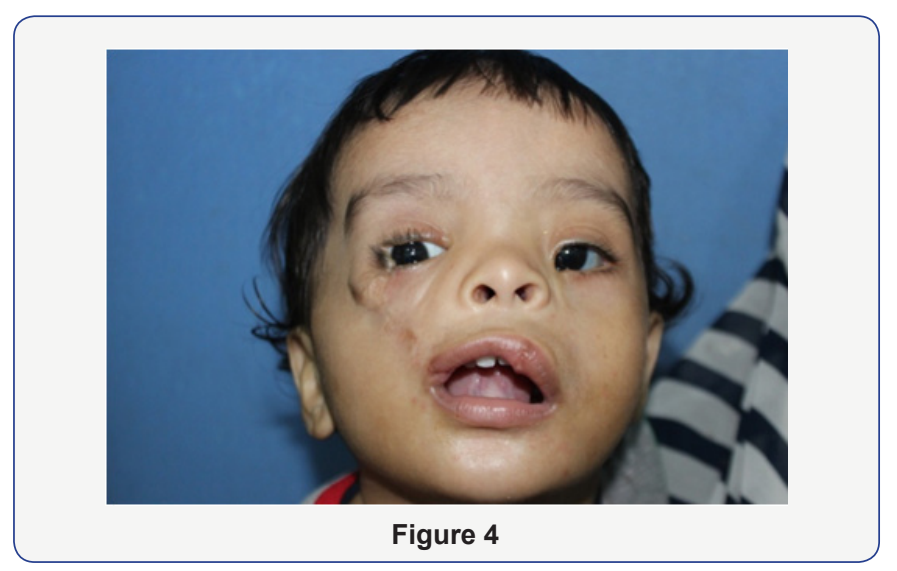

\section{Discussion}

The prevalence of these groups of facial clefts is less than $0.25 \%$ among all facial clefts [5]. Morian (1887) labeled this as a type II oro-ocular coloboma; whereas, Boo-Chai (1970) called this a type II oro-ocular cleft. Karfik (1966) termed this a true oblique cleft, and van der Meulen [6] described this as lateral maxillary dysplasia. Tessier [7] originally published his widely used classification that designates this defect as a no. 5 cleft. Tessier postulated that the no. 9 cleft would be a northbound version of this no. 5 cleft [7]. As described by David et al. In (1989).

The embryological aspect of these clefts remains ambiguous although morphology of these clefts can be explained on the basis of early embryonic development of the face. If the arrest occurs before the different processes have merged at the 17- mm crownrump length (CRL) stage, the lacrimal canal will fail to form, and a primary or transformation defect will be formed such as primary clefts, Tessier numbers 3 and 7. If the disturbance takes place after closure of the ectoderm of the face has been completed and a canal has been produced, before the end of the differentiation phase at 60-mm CRL stage, a secondary or differentiation defect will result such as secondary clefts, Tessier numbers $1,4,5,6,8,9,10,13$, and 14 [6].

There are several theories of etiopathogenesis of oblique facial clefts. One of these theories is that oblique facial clefts are caused by a developmental arrest such as focal fetal dysplasia, and a variety of mechanisms has been suggested, such as linear necrosis, diminished arterial supply, disturbance in the migration of neural crest cells, or failure of mesodermal penetration and coalescence between facial processes[6]. This theory seems to explain the formation of the primary clefts.

The objective of the surgery is to close both the eyelid and the labiomaxillary cleft; elevate the lateral canthus; and reconstruct the orbital floor, the malar bone, and the body of the maxilla with bone grafting at the later stages of life. Surgical approximation aims at approximation of two muscles orbicularis oris and orbicualris oculi, along with multiple level 'Z' plasties for skin approximation to avoid a straight line closure that can lead to a scar contracture in future.

Kara and Ocsel [8] have reported a case in which they reconstructed the patient's soft tissue using multiple ' $\mathrm{Z}$ ' plasties at 8 days of age, leaving the skeletal defect to be repaired later. Tessier (1977) postulated that the orbital dystopia is important to treat prior to 12 months of age. In facial clefts affecting the eyelid region with corneal exposure, surgery must be undertaken as soon as the child can be stabilized. Ophthalmic lubricant ointment for the exposed cornea can be used [5].

\section{Conclusion}

In conclusion we present a case of tessier cleft $4 \& 5$ facial cleft. Surgical techniques that can be used were presented in the article; according to us early repair using multiple $\mathrm{Z}$ plasties to avoid contracture of the scar is an accepted surgical modality. An increased number of cases and a long follow up would be required for any analytical results with respect to the different techniques mentioned [9-12]. 


\section{References}

1. Kawamoto HK (1976) The kaleidoscopic world of rare craniofacial clefts: order out of chaos (Tessier classification). Clin Plast Surg 3(4): 529-572.

2. Natsume N, Tsukawaki T, Kuno J, Kurita K, Kawai T (1999) Survey of patients with oblique facial clefts in Japan. J Oral Maxillofac Surg 28(1): 53-55.

3. da Silva Freitas R, Alonso N, Shin JH, Busato L, Dall'Oglio Tolazzi AR et al. (2009) The tessier number 5 facial cleft: surgical stratagies and outcomes in six patients. Cleft Palate Craniofac J 46(2): 179-186.

4. Galante G, Dado DV (1991) The Tessier number 5 cleft: a report of two cases and a review of the literature. Plast Reconstr Surg 88(1): 131135 .

5. Abdollahifakhim S, Shahidi N, Bayazian G (2013) A Bilateral Tessier Number 4 and 5 Facial Cleft and Surgical Strategy: A Case Report. Iran J Otorhinolaryngol 25(73): 259-262.

6. van der Meulen JC (1985) Oblique facial clefts: pathology, etiology and reconstruction. Plast Reconstr Surg 76(2): 212-224.
7. Tessier P (1976) Anatomical classification of facial, craniofacial and laterofacial clefts. J Maxillofac Surg 4(2): 69-92.

8. Kara IG, Ocsel H (2001) The Tessier number 5 cleft with associated extremity anomalies. Cleft Palate Craniofac Surg 38(5): 529-532.

9. Chiong AT, Guevarra ES Jr, Zantua RV (1981) Oblique facial cleft. Arch Otolaryngol 107(1): 59-62.

10. Darzi MA, Chowdri NA (1993) Oblique facial clefts: a report of Tessier numbers 3, 4, 5 and 9 clefts. Cleft Palate Craniofac J 30(4): 414-415.

11. Menard RM, Moore MH, David DJ (1999) Tissue expansion in the reconstruction of Tessier craniofacial clefts: a series of 17 patients. Plast Reconstr Surg 103(3): 779-786.

12. Pereira FJ, Milbratz GH, Cruz AA, Vasconcelos JJ (2010) Ophthalmic considerations in the management of Tessiercleft 5/9. Ophthalplas Reconstr Surg 26(6): 450-453.

13. Uchikawa Y, Ogata H, Hattori N, Miyamoto J, Nakajima T (2011) Palatoplasty for bilateral oblique cleft of the soft palate accompanied by tessier number 5-7 cleft. Cleft Palate CraniofacJ 48(2): 231-235.

\section{Your next submission with Juniper Publishers will reach you the below assets}

- Quality Editorial service

- Swift Peer Review

- Reprints availability

- E-prints Service

- Manuscript Podcast for convenient understanding

- Global attainment for your research

- Manuscript accessibility in different formats

( Pdf, E-pub, Full Text, Audio)

- Unceasing customer service

Track the below URL for one-step submission https://juniperpublishers.com/online-submission.php 